\title{
University Students' Perspective on Material and Activities in English Listening Class During Pandemic
}

\author{
Neni Nurkhamidah \\ Sekolah Tinggi Keguruan dan Ilmu Pendidikan Media Nusantara Citra, Jakarta, Indonesia \\ neni.nurkhamidah@stkipmnc.ac.id
}

\begin{abstract}
ARTICLE HISTORY
Received : 12 May 2021

Revised : 29 May 2021

Accepted : 6 June 2021
\end{abstract}

\section{KEYWORDS}

Online Learning

Listening

Covid-19 Pandemic

Higher Education

Students'Perspective

Learning Material

Learning Activities

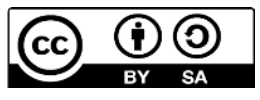

\begin{abstract}
The most obvious impact of Covid-19 in the education field is the shifting of face-to-face classroom meetings into online learning. Since fully online learning is new for most universities in Indonesia, teachers have to abruptly prepare effective learning material and activities to support student learning in distance. Several studies on listening classes in Indonesia have been carried out during the Covid-19 pandemic, but studies that focus on student's perspectives on the material and activities in English listening class in higher education have not been conducted yet. This study fills this research gap because students' perspectives are important to improve the quality of listening-focused courses. This study is conducted on January 2021 by involving nine English Education students enrolled in the Basic Listening class at the STKIP Media Nusantara Citra. Questionnaires and interviews are employed to collect qualitative data. Despite the abruptness of creating and adapting new materials with an unfamiliar learning style, results showed that students have a positive perspective toward the effect of the lecturers' materials on their learning motivation, the usefulness of the material, the level of difficulty and quantity of the material and activities, the variety of material and activities, the usefulness of pre- and post-listening activities, the quality of audio and the suitability of worksheet.
\end{abstract}

\section{Introduction}

At the beginning of 2020, Covid-19 occurred and started to spread widely entire the world. This quick spread drove many countries to lock down their area. As a result, various sectors such as economic, education, and health suffer from loss (Rahim \& Chandran, 2021). Chriscaden (2020) in a joint statement with International Labor Organization, Food and Agriculture Organization and International Fund for Agricultural Development states that Millions of companies face bankruptcy threats. Almost the 1.7 billion workers around the world are at risk of losing their job. Informal industry workers also face more horrible situations because most of them do not have health and social insurance that protect them during the pandemic. Without earning money as their income during pandemic lockdowns, many people cannot provide food for themselves and their families. This situation results in health issues due to nutritional deficiency.

It is reported by The United Nations Educational, Scientific and Cultural Organization (2020) that $87 \%$ of the world's educational institutions or are closed as the effect of COVID-19. It is also mentioned that over 1.5 billion students in 195 countries have to study at home. And the existence of distance learning with technology or online learning is considered as the practical solution, that helps students, teachers, and parents in pandemic crisis. Universities in Indonesia also quickly implement government regulations by closing their campuses to protect their lecturers and students from the Covid-19 spread (Putri et al., 2020; Syafiq et al., 2021). Then, all teaching-learning activities suddenly switched to distance teaching-learning by using technology. Although educational institution closure may disrupt the teaching and learning process as it happened in the outbreak of the influenza virus (Jackson et al., 2016), the emergence of the Covid-19 pandemic triggered technology transformation, especially in higher education.

The normal process of transformation may take many years to be ready, but the emergency online learning forces teachers to take only several weeks to prepare for the learning (Strielkowski, 2020). The quick transformation is intended to provide the opportunity for the student to keep learning during the health crisis. Online learning that is conducted remotely offers safe teaching-learning for students and teachers. In this crisis, online learning is not an option, it is a must. Liguori (2020) explains that online learning is the best solution for education in the current situation. Educational institutions must find innovative solutions dealing with the pandemic. Educational institutions must find innovative solutions to deal with the pandemic. Adedoyin \& Soykan, (2020) emphasize that teachers have to see online learning as a moment to transform opportunity not as an emergency to make a sustainable process in online learning.

It is widely considered in Indonesia that learning English is not easy because students have to learn its vocabulary, pronunciation and other rules that contradict with their mother tongue (Sundari, 2018). Besides the difficulty, 
several factors such as students' personal problems, lecturer, facility, and syllabus also determine the success and failure of English teaching and learning (Zahidi, 2014). The school environment, teacher, and parents are founded by Hanus (2016) as the factors that affect students' English learning achievement. Although teachers and students are familiar with English class in face-to-face form, problems inevitably occur with the abrupt change to online learning format. Moreover, in a fully online class, the problem may occur because it is a new experience for them. Reading, writing, listening and speaking, i.e., the four cornerstones of English language skills in Indonesia's formal syllabus, have to be delivered in distance by technology and the teacher has to make sure that all students engage with the material.

This study is motivated by the fact that universities had to improvise their learning materials and activities to accommodate the changes caused by Covid-19 pandemic, but it is possible that not all four skills of English language are equally updated. Listening might be a prerequisite skill for other skills in English learning, but in fact, listening skill is one competence that sometimes is neglected in Indonesia (Yulita \& Jumiyanti, 2021). Ulum (2014) states that this skill is sometimes called "Cinderella skills", a common term for referring to its position that is overlooked in formal language learning due to being excluded from official testing in Indonesia's final or national exams. At the same time, listening skill is judged as a hard and problematic language skill for EAL and EFL students because of the narrow chance of practicing this skill in the real context (Nowrouzi \& Tam, 2015). Teaching listening may be hard for Indonesian teachers, and "mastering the English listening skill" may be hard for students. Nushi \& Orouji (2020) mention that students' three major-based difficulties in learning listening. Those three difficulties are pronunciation, personal characteristics, and content. Izzah \& Keeya (2019) find that distortions, vocabularies, phonology, passage complexity, and the speech rate are the common difficulties for students in listening class due to the variety in pronunciation, individual characteristics, and content.

Despite the general disregard on listening skill, institutions do acknowledge its significant role for language learning and communication, especially in advanced courses such as businesses or international relations (Gajšt, 2014; Prihandoko et al., 2019). One such attempt of training students' listening skill is the Basic Listening course given to students of the English Department in STKIP Media Nusantara Citra. In this course, students have to identify the various purposes and other relevant details in English conversations and talks in daily life. This study's purpose is to improve the course's by evaluating the students' perspectives of the materials and activities that the lecturers of this course has created with less-than-ideal preparation time. Training students' listening skill in a full online format is a new experience for the lecturers and students of this selected university. What makes the difference between both teaching listening online and face-to-face in the classroom is that in teaching the online teacher is challenged to choose the most suitable tool that supports the activities. When in a traditional classroom the recording is directly presented by using the audio tool and it is easy for the teacher to manage the class, but in online learning, the audio has to be delivered to a certain platform. Then students have to download it to listen to or the teacher will play the recording in a virtual meeting with the consequences that not all students can listen to the audio clearly due to internet connection problems.

Many types of research on teaching and learning during pandemics have been conducted. Putri (2020) in the study on listening class at a pesantren-based university shows that teachers need to assist the students in online learning activities especially in the use of the Internet, books, and dictionary. She also emphasized that an effective teacher refers to a teacher who can assist and help students in the learning process. Therefore, in a pandemic situation, the exitance of an effective teacher is needed to obtain successful learning in an online class.

Susilowati (2020) investigate the challenge faced by teachers of a university in teaching online listening. She found out that choosing the suitable Information and Communication Technology (ICT) devices, the choosing of learning application, the material packaging, material delivering, teaching method, and teaching strategy as the challenge for the teacher in implementing online listening class. It is suggested that the choice of learning technology devices and applications should be affordable for students and teachers. The material used in listening class should be simpler than that one in offline class. Learning material should be taken from various sources to avoid the students' boredom. Since some students have limited internet access and virtual meeting cannot always be implemented, teachers have to encourage students to learn independently. If the learning objectives cannot be achieved, the student's teacher can utilize listening logs to help them to practice listening independently.

The next research is research conducted in an English education program of a university in Banjarmasin by Aldina (2020). This study focuses on students' challenges with online listening learning during the pandemic. This research results in some findings of internal and internal factors faced by students in online listening classes. It is suggested that students need to do more intensive exercises to strengthen their listening skills. Song and movie are two types of learning material that can be used in learning to listen. Because there are many challenges faced by students, teachers have to implement a good strategy to help them face the challenges.

Qiong (2017) indicates that perception is a person's awareness or understanding of particular information. In the education field, students' perception refers to the students' understanding of their learning process related to what they have seen, heard, and touched. There are three-stage of the perception process. First is selection, the stage when a person converts the stimuli of the environment to a meaningful experience. The second is called organization. In this stage, 
a person organizes or grouping the experience. And the last is interpretation. A stage in which a person interprets the stimuli. The interpretation created by people may be different because there are so many internal and external factors affected by persons' interpretation. Investigating students' perspective on the material and activities implemented in listening class in online learning environment is necessary because material and activities are elements that affect students on listening class (Aldina, 2020; Nushi, 2020). Many types of research on teaching and learning during pandemic have been conducted, but they do not focus on students' perspective related to learning material and activities, less so on a course focused on listening skill. That is why this research will contribute to the recent trend of highlighting listening skill's equal importance with the other three cornerstones of English language skills for EAL and EFL students.

\section{Literature Review}

\subsection{Indonesia's Educational System During Pandemic}

At the beginning of 2020, Covid-19 pandemic did not stop spreading throughout the country, so the Indonesian Circular Letter Number 4 the Year 2020 is still enforced. It impacts the continuity of learning from home as one of the government policies in the letter. This also means that online or distance teaching-learning because classroom teaching and learning in all levels of education are still not allowed to be implemented.

The different condition among educational institution in Indonesia results in different readiness for the institutions to implement online learning. Many institutions are successful in conducted online learning. On the other hand, many institutions face challenges in online learning implementation. Churiyah et al. (2021) in their research that explores university readiness on online learning reveals that teachers, students, and facilities elements are needed to improve to make Indonesia's university ready with online learning implementation. They also point out although the virtual infrastructure has been prepared well, not all students are ready to have fully online learning because their selfregulated learning is very low. Therefore, they cannot manage and regulate their learning activities.

Saintika et al. (2020) assess the readiness of public and private universities in Central Java to conduct online learning during the pandemic. Two elements measured in this study are the institution and students' factors. It is found that the universities are ready to implement online learning with some improvements by creating asynchronous multimedia learning content, increasing the number of workshops related to the use of application for online learning, establishing policies about the requirement to use online learning platform set by universities, and making a plan about the facilities especially in internet bandwidth and learning platform storage capacity.
Wulanjani and Indriani (2021) investigate students' readiness in a public university by assessing students' internet self-efficacy, communication self-efficacy, selfdirected learning, learner control, and motivation to learn. The result of the study concludes that motivation is the highest contribution to keep them learning online during a pandemic. On the other hand, learner control is the biggest challenge for students in online learning. Students mention that their learning is distracted by other online activities. It is suggested that teachers improve the online learning quality, by implementing various learning instructions and activities.

A study on students' perspectives about online learning in speaking class reveals that online learning does not help them in improving their speaking skills (Fitriani et al., 2020). Another study on writing and reading during pandemics finds that teachers employ silent reading, skimming, and scanning activities. While in writing class, the teacher implements the planning, drafting, revising, and publishing activities (Setyowati et al., 2021), The major obstacle during teaching reading and writing is students' vocabulary mastery. For listening skills, students prefer monologue and dialogue with 30 minutes of activities listening to native speaker conversation (Destianingsih \& Satria, 2020). Regarding the media used in online teaching Google Classroom, WhatsApp, and Zoom are commonly used by the teacher in conducting online teaching (Hamid, 2020). Since there are many challenges in implementing online learning, all elements have to be prepared properly. Teachers as teaching facilitators have to set material, activities, technology, and assessment for the success of online learning.

\subsection{Online Learning}

Digital transformation in higher education institutions is not a new phenomenon. Taking a look at the process, digital transformation is not an easy thing because it is a peak process of applying digital technology that needs adequate preparation, well-prepared strategies, sufficient organization knowledge, collaboration, and reinforcement of all parties involved in the process (Balyer, 2019). Online learning is regarded as the manifestation of digital transformation. This type of learning has been recognized in many Indonesian higher educations before pandemics occurred. However, the online learning is only the supporting activities that students can take independently outside the class hour. This form of learning is called "blended learning", which gives online learning without neglecting traditional class interaction, so both face-to-face meetings in the classroom and online activities are simultaneously conducted (Halili \& Zainuddin, 2015). Blended learning allows students to find more learning resources, collaborate with their friends, and discover new ideas.

The effectiveness of online learning in higher education has been founded in several studies. Bahasoan et all (2020) in a study entitled "Effectiveness of Online Learning in Pandemic Covid-19" find that online learning carried in the University of West Sulawesi is efficient in terms of teaching- 
learning activities. On the other hand, it is also founded that online learning is not efficient. The inefficiency regarding the cost. Students state that they spend higher costs in online classes than in offline classes because of the need to buy internet data. A study conducted by Suprianto, Arhas, \& Mahmuddin (2020) reveals that online learning conducted at the University of Borneo Tarakan is effective. It is proved by high students' satisfaction toward online learning, learning quality improvement, behavior change, and the increasing of learning outcomes category.

Although online learning is recognized effective to be applied in the Covid-19 pandemic, there is a huge number of challenges in its implementation. In the Indonesian context, one of the online teaching-learning challenges happens because teachers and students do not support particular technology such as internet connection, computers, laptops, and smartphones (Efriana, 2021). It is further mentioned by Belay (2020) that the changing of the traditional education system to distance education brings disadvantages for students from low-income or rural families. This is a big task for the government and teachers to find the fittest way to help students in distance education during the pandemic.

Son et al (2020) state that long-lasting COVID 19 brings negative effects to the mental health of students in higher education. Stress and anxiety are increasing due to the fear of the virus, concentrating difficulty, sleeping pattern disruption, social interaction limitation, and academic performance concerns. A study by Lischer, Safi \& Dickson shows that personal health issues, the concern on academic delay are factors causing students anxiety during the pandemic. It is suggested that students need to be prepared for the probable learning workload. Another research reveals that students experience a heavy workload in learning during the pandemic that affects students' psychology, such as anxiety, boring, and mood change (Irawan et al., 2020). Online learning is also affecting students' physical health. Lack of time to sleep and lack of physical activities because they spend most of their time sitting in front of the computer to do the assignment (Balram,2020). Since the transition from offline learning to online learning affects students, teachers, and institution staff. Many factors need to be examined. Curriculum the human condition, and the facilities are some dimension need to consider as the factor that leads to the success of online learning.

In the Indonesian context, one of the online teachinglearning challenges happens because teachers and students do not support particular technology such as internet connection, computers, laptops, and smartphones (Efriana, 2021). It is further mentioned by (Belay, 2020) that the changing of the traditional education system to distance education brings disadvantages for students from lowincome or rural families. This is a big task for the government and teachers to find the fittest way to help students in distance education during the pandemic.
Online learning can be grouped into two general learning environments, namely synchronous or real-time online learning and asynchronous learning (Perveen, 2016). Synchronous online learning provides opportunities to meet virtually at the same time. The interaction can be supported with a video call or chat. Synchronous online learning allows students to listen to their teachers directly as listening input and get direct feedback from a teacher. On the other hand, asynchronous online learning provides the learner with readily available material. It is shown that the implementation of asynchronous in language learning is quite beneficial with the support of synchronous learning. It is suggested that teachers blend both synchronous and asynchronous in the online learning environment.

Several platforms such as Learning Management System (LMS) YouTube, video conference tools, and media social are available to be accessed for educational purposes. Basilaia et al (2020) mention that Google can be utilized as a useful platform in this problematical situation. There are also many products offered such as Gmail to exchange the data, Google Classroom to share the learning material, Google Form to run the quizzes, Google Drive to store the data, Calendar to schedule the learning, and Hangouts Meet to conduct a virtual meeting with students. Padmo \& Ardiasih (2020) emphasize some possible platforms, such as Skype, Teams, Webex, Google Meet, and Zoom. Utomo et al (2020) recommend a combination of Google Classroom, WhatsApp, and Zoom for online learning. It is also recommended the use video conference only in practical sources to decrease the use of internet data. By considering the strengths and weaknesses, the university can choose various learning platforms to support their students in distance learning.

\subsection{Learning Listening}

The first skill received by a person is listening. This skill belongs to the receptive skill that is very fundamental for other skills especially speaking. The process of listening does not stop on receive the sound. The listeners have to understand the meaning of the sound. The percentage of listening in communication takes 40-50\% (Yildirim, 2016). To support students in listening, numerous types of listening material and activities could be applied.

Rost (2011) groups listening into six categories (1) intensive listening, (2) extensive listening, (3) responsive listening, (4) interactive listening, (5), autonomous listening and (6) selective listening. In intensive listening, students will comprehend the specific unit of discourse such as grammar, pronunciation, and vocabulary. Intensive learning is used in EAL and ESL context to measure students' phonological and morphological skills. Extensive listening is listening with a longer time and larger amount of discourse with pleasure input. In designing an extensive listening task, teachers have to maximize benefit and minimize learning problems during the activities. Giving general feedback in this type of listening is also needed $(\mathrm{Gu}, 2018)$. Responsive listening is listening that expect appropriate response or 
reaction from the students. In responsive listening, student's ability in comprehending the discourse is the main goal of the learning. Interactive listening provides the students with the ability to engage in a social context. Autonomous listening is a listening activity that supports students to work independently and this type of listening fits to be implemented during the pandemic. Intelligence (AI) is recommended by $\mathrm{Hu}$ and $\mathrm{Hu}$ (2020) as an effective tool to provide autonomous listening. The website can also be used to assist students' learning (Surayatika, 2017). The students' condition has to be considered in choosing material and activities because the success of learning is influenced by teachers and students' convenient work environment.

\subsubsection{Learning Material on Listening Class}

Learning material is everything used by a teacher to distribute messages for creating an effective and efficient learning environment. Due to the complexity of teaching English listening in the online environment, material selection has to implement to meet the students' needs and conditions. English songs, news, podcast, movie, conversation, and talks are common types of material given in English class. Introducing students with different accents is also a necessity because when students only listen to the same accent, it will be hard for them to understand speakers with different kinds of accents (Büyükahıska \& Uyar, 2020). That is why teachers need to implement present the material with different types of accents to help to recognize the variety of English accents.

Current technology development also enriches the variety of listening material. Chien et all (2020) point out that YouTube does not only appeal to the students' attention to learning but also helps the students to perform better in language class. The audio podcast is also found effective to teach students both in the classroom or in an online class (Fachriza, 2020). The existence of Information and Communication Technology must be utilized by teachers to support their online teaching.

Using authentic material in learning listening is also beneficial. Kholida (2016) mentions the use authentic material is effective for university students. Currently, various types of authentic listening material can be found in the form of authentic audio material, authentic visual material, authentic audio-visual material, and authentic printed material. Authentic audio and audio-visual learning material are two kinds of material that can be applied in listening classes. The materials include movies, songs, TV commercials, TV news, Radio News, and shows.

\subsubsection{Learning Activities on Listening Class}

Besides the type of learning material, the teaching technique and method are also needing to be considered. The various instruction such as transfer information, answer questions, paraphrase, translate and summarize can be used in the class (Nor, 2014). The use of the game is also recommended to be implemented to develop students' skills. The teacher can develop their own digital game or adapted the game for listening activities. There are also huge numbers of the free or paid website provide worksheets can be downloaded by teachers to be applied in listening activities.

Djabborova (2020) states there are three main phases of listening activities as the strategy to engage the student in learning listening: 1) pre-listening activities, 2) whilelistening activities and 3) post-listening activities. In prelistening activities, the teacher checks students understanding of the vocabulary and triggers students to predict the learning content. In while-listening activities, students listen to the listening material prepared by the teacher and do the main activities. In the last phase, postlistening activities students check their work and summarize the lesson.

Schmidt (2016) recommends a journal web-based activity in English listening class. In this activity's students will be given a short video to watch. The students then take notes of important information they get from the video. After that students will complete the gap fill. In the final step, the teacher will give the same video with subtitles to find the gap. The use of Ted Talk is also recommended. In this activity, students will be free to choose the video on www.ted.com. In this activity, students will watch the video three times. The first watch is without any subtitles, the second is with English subtitles and the last is with the first language subtitle. On all three watching activities, students will make notes. Then at the end of the activity, they will compare the note they make

\section{Method}

This is qualitative study aims at exploring listening online learning during pandemic from students' perspective on two areas, namely their perspective on the listening class' learning materials and learning activities. Nine students in the Basic Listening class at the English Education Department of STKIP Media Nusantara Citra are involved in this research. A questionnaire that consists of 10 items is distributed. To support the questionnaire data, the interview is also employed. In the interview session, students answer 10 questions. The questionnaire and interview items are modified from Putri (2020).

The data collection process took three days in total. The first step is developing questionnaires and interview items. Two aspects covered in the items are learning material and learning activities in listening class. The next step is distributing questionnaires to students by google form. After students finishing their answers on questionnaire items, the researcher collects and administrates the data. The next day researcher then conducts an online interview by using Google Meet. The interviews took no more than 10 minutes for each student. It took three days to finish the interview sessions with students because not all students were willing to be interviewed on the first day. The next step is analyzing data from the questionnaire. In this step researcher by 
reading the data, organize, categorize, generate and interpret the data.

Table 1. The Questionnaire Scoring

\begin{tabular}{lll}
\hline Remark & Value & Range \\
\hline Strongly Agree & 5 & $4.21-5.00$ \\
Agree & 4 & $3.41-4.20$ \\
Neutral & 3 & $2.61-3.40$ \\
Disagree & 2 & $1.81-2.60$ \\
Strongly Disagree & 1 & $1.00-1.80$ \\
\hline
\end{tabular}

Likert scale is employed with questionnaires scoring as it is presented in Table 1. After the data from the questionnaires are analyzed, the researcher analyses the data from the interview by coding, analysing, and interpreting the data. The last step of this procedure is presenting the result in a descriptive qualitative was as the result of the study.

\section{Results \& Discussion}

The result of the questionnaire and interview will be presented in three-point: a) learning material, b) learning activities, and c) assignment. The following explanation will answer the research objective.

\subsection{Learning Material}

The result of the student's perception of the material is presented in the following table

Table 2. The Material in Listening Class

\begin{tabular}{llll}
\hline No & Questionnaire Items & Means & Remarks \\
\hline 1 & $\begin{array}{l}\text { The listening materials } \\
\text { improve my motivation } \\
\text { to learn } \\
\text { The listening material } \\
\text { given by lecturer is } \\
\text { useful } \\
\text { The level difficulty or } \\
\text { the material is } \\
\text { appropriate } \\
\text { The quantity of } \\
\text { material is appropriate } \\
\text { The audio has good } \\
\text { quality }\end{array}$ & 4.3 & $\begin{array}{l}\text { Strongly } \\
\text { Agree }\end{array}$ \\
& 4.1 & Agree \\
& Agree \\
\hline
\end{tabular}

As it is shown in Table 2, students strongly agree that the listening materials improve their motivation to learn. The existence of motivation in learning listening is crucial because motivation and listening skills achievement are correlated(Ajmal \& Kumar, 2020). It is also found that students' motivation on learning listening during the pandemic is decreased. That is why the learning material provided by a teacher should increase students' motivation to achieve the learning goal. The factors that motivate students to learn are new information and information they get in the listening class, interesting material, and various kinds of English accents.

"Listening to the conversation recording in Basic Listening class motivates me to learn more because I get important information how I have not known yet, so it makes me learn more and more."

\section{Excerpt 1}

"I think learning from songs and news in listening class is interesting. It makes my motivation to learn listening come with me because sometimes I'm afraid of listening to long recordings."

Excerpt 2

"The audio recording and video given by teachers involves different types of accents, it is new for me to learn it. I enjoy this class."

Excerpt 3

When the researcher asks why the listening material motivate them to study, the students gave different answers, as shown in Excerpt 1, 2, and 3. In Excerpt 1, a student tells that the motivation in learning listening comes from the new information obtained in the English conversation. Curiosity and interest as part of learning behaviors have an important role in knowledge acquisition Murayama (2019). Therefore, teachers have to be able to choose appropriate learning material to trigger student's curiosity and interest in learning.

Another response shown in Excerpt 2 indicates that song is the type of material that develops motivation. This finding is supported by Faliyanti (2021) that found the song as listening material that enhances students' motivation and vocabulary mastery because it brings an enjoyable atmosphere to the classroom. Singh (2020) also claim the song is fun and interesting learning material that improve student's motivation and English proficiency skill

The next is the different types of accents presented in the listening class is mentioned by a student as the factor that motivates him in listening class as it is shown in Excerpt 3. Büyükahıska \& Uyar (2019) say that it has been proved that people with different nationalities will have a different pronunciation of the same word. This is interesting for students because for some of them this is a new matter. EAL and EFL students need to be trained by using listening material with a different accent. Teachers have to select the material properly by the level of student ability in listening.

"After learning listening by using news, I try to independently listen to English news. And now I'm interested in listening to English news online. So, I think what I learn is very useful"

Excerpt 4 
"In Basic Listening class I learn phrases used by English native speakers in conversation. There are many phrases are new for me. I will use the phrases when I talk in English to people in the inside or outside the class"

\section{Excerpt 5}

"The topic of the listening materials relates to my daily life like shopping, traveling, presentation and listening to a lecture, and many more. It is useful especially listen to lectures and presentations. Because most of the course are presented in English, students have to get used to listen to lectures in English"

\section{Excerpt 6}

The second part of the questionnaire is the learning material usefulness, which was met with various responses as it is shown in Excerpts 4, 5, and 6. In Excerpts 4 students mention that English news is regarded as interesting material for students. Because news is the quite long discourse, Zulfikar et al (2020) recommend that the use of news have to consider the difficulty level and the topic. It is important to carefully select material based on the students to need and commonly the need of the learners has been written in the syllabus. The result of the questionnaires indicates that the students agree that the listening material given by the lecturer is useful. This result is also supported by the interview when the teacher asks them what matters listening material be useful for your life.

"Sometimes the people in the recording talk too fast and I don't understand what they talk about"

\section{Excerpt 7}

"The recording is too long, I missed some information because I forget what the speakers say"

\section{Excerpt 8}

The next is about the level of difficulty of the listening materials. Based on the questionnaire, it is found that students agree that the level of difficulty or the material is appropriate. In this case, "appropriate" means that the materials are not too difficult as well as not too easy. Based on Excerpts 7 and 8, the students identified some factors that made them think that the materials are difficult for them. Nushi \& Orouji (2020) listed the problem faced by the students in listening class. The factor founded as the common problem in listening are unfamiliar vocabulary, noises distraction that make students lose the concentration, poor sound conditions, unfamiliar slang and idioms, students do not accustom to high rate of speech, students experience distraction and tiredness when listening to a long text, unfamiliar with the topic and lack the interest of the topics.

The result of the questionnaire shows that the number of listening materials given by the teacher is appropriate for students. The next item is about the audio quality audio has good quality because it may be the constrain of the listening class (Nushi \& Orouji, 2020). The clarity of sound is affected not only by the quality of the material but also by the tool used by students to play the audio or video. In an online listening class, the teacher uses MP3 recording material that is sent to students, YouTube, English sing, and listening resources on the website. The result of the questionnaire indicates to students that the sound of materials has good quality.

However, problems seem to occur when students feel stressed due to encountering difficulties. Some researches reveal that online learning impact on stress and anxiety for university students (Sundarasen et al., 2020; Yang et al., 2021). To help students to cope with the stress, it is suggested by (Al-kumaim et al., 2021) that teachers should motivate the students to develop self-confidence and selfefficacy in learning. Universities also need to manage the quality of online learning content by assisting the teacher in planning and designing the activities and material.

\subsection{Learning Activities}

The second area to be studied in this study is learning activities. The result of the questionnaire related to learning activities is presented in the following table:

Table 3. The Activities in Listening Class

\begin{tabular}{llll}
\hline No & Questionnaire Items & Means & Remarks \\
\hline 1 & $\begin{array}{l}\text { Pre and post listening } \\
\text { activities help me in } \\
\text { the listening class } \\
\text { The activities in } \\
\text { listening activities are } \\
\text { varied }\end{array}$ & 4.6 & $\begin{array}{l}\text { Strongly } \\
\text { Agree }\end{array}$ \\
3 & $\begin{array}{l}\text { The activities in the } \\
\text { class is interesting }\end{array}$ & 4.2 & Agree \\
4 & $\begin{array}{l}\text { The quantity of } \\
\text { assignment is } \\
\text { appropriate } \\
\text { The worksheet given is } \\
\text { suitable with the audio }\end{array}$ & 4.5 & $\begin{array}{l}\text { Strongly } \\
\text { Agree } \\
\text { Agree }\end{array}$ \\
5 & 4.6 & $\begin{array}{l}\text { Strongly } \\
\text { Agree }\end{array}$ \\
\hline
\end{tabular}

The result of the questionnaire points out that students strongly agree that pre- and post-listening activities help them in the listening class. The students' perception of preand post-listening activities shown in Excerpts 9, 10 and 11.

"Pre-activities helps me predict what we will do in listening class"

Excerpt 9

"In pre-listening activities, I learn vocabularies that will be used in listening activities. Some vocabularies are new for me. When I know the meaning of the vocabularies, it will be easy for me in listening activities"

Excerpt 10

"Teacher helps students to remind what they have learned and summarized the lesson, it is important for me because sometimes I miss important information in the class"

Excerpt 11 
Having online learning too long with no certainty when classroom learning will be opened, students respond to the implementation of online learning with a different attitude. A study by Male et al. (2020) revealed that students tend to be bored with online learning. It is suggested that teachers should design various activities to reduce student's boredom. In the Basic Listening class, teacher employed various types of activities, such as watching videos on YouTube, online advertisements, English songs, and games to avoid students from boredom. The activities were also designed as interesting as possible to motivate students. Based on the questionnaire, it is concluded that students agree that the activities are varied, and they strongly agree that the activities are interesting.

"The activities are not monotonous. We listen to the song, watch a short video, YouTube, and listen to our friends talk"

\section{Excerpt 12}

"The most interesting activities is watching a short video, funny advertisement, then we explain the important information on the video we watch"

\section{Excerpt 13}

Regarding the quantity of the activities, the questionnaire result shows that students agree that the activities fit time. This data is in line with the interview results as shown in Excerpts 12 and 13. Basic Listening is a-three credits course. It is a big task for the teacher to make the 3 credits ( 3 x 50 minutes) bring benefit to students' learning. The last point to be observed is the suitability of the worksheet with the audio. There are many practical benefits of using the worksheet in learning (Kasap, 2016). Therefore, teachers have to prepare well-developed worksheets before teaching. In listening class worksheet support learning activities because it guides students to do activities and monitors students' progress. The worksheet is developed based on the audio or video given, that is why the teacher has to be careful in developing a listening worksheet. The result of the questionnaires shows that students strongly that the worksheet used in the class fits the audio.

To sum up the result of the whole analysis, it is shown that students have a positive perspective toward the effect of the material on their learning motivation, the usefulness of the material, the level of difficulty and quantity of the material and activities, the variety of material and activities, the usefulness of pre- and post-listening activities, the quality of audio and the suitability of worksheet. Although the material and activities conducted in listening class are appropriate for students, there is still some development that needs to apply especially related to length and the rate of speech of the audio. The teachers should examine that aspect to improve the quality for the next online listening class.

\section{Conclusion}

It is not easy to conduct an English Listening class during the pandemic, especially for universities where full online classes will be a first experience for both teachers and students. This study contributes to Indonesia's continuous effort of adapting with online learning during pandemic by revealing the students' perspectives on the learning material and activities of the course of a generally neglected English language skill. Since fully teaching-learning listening in an online environment is new in Indonesia, learning materials and activities as part of online learning must be designed in a well-prepared way. This is crucial because learning affects the success of students' learning.

To make sure that material and activities are appropriate to be implemented in online learning, the researcher explores students' perception of learning materials and activities applied in listening class. The results of this research revealed that students show positive perceptions toward the material and activities given in Basic Listening class. It is suggested that English listening teachers employ pre- and post-listening activities, use various materials and activities, consider the quantity of material and activities, make sure that the audio quality is proper and provide a suitable worksheet. The researcher will use the result of the study as the consideration in designing the online listening material and activities for future listeningfocused class.

\section{References}

Adedoyin, O. B., \& Soykan, E. (2020). Covid-19 pandemic and online learning: the challenges and opportunities. Interactive Learning Environments, 28(1),1-13. https://doi.org/10.1080/10494820.2020.1813180

Ajmal, M., \& Kumar, T. (2020). Inculcating Learners' Listening Motivation in English Language Teaching: A Case Study of British Education and Training System. Arab World English Journal, 11(4), 409-425. https://doi.org/10.24093/awej/vol11no4.26

Aldina, M. (2020). Students' Challenges In Listening In Virtual Classroom ; Case Study In English Education Study Program In Covid-19. 2020, 109-112. https://ojs.uniskabjm.ac.id/index.php/PIUOK/article/view/3986

Al-Kumaim, N. H., Alhazmi, A. K., Mohammed, F., Gazem, N. A., Shabbir, M. S., \& Fazea, Y. (2021). Exploring the Impact of The Covid-19 Pandemic On University Students' Learning Life: An Integrated Conceptual Motivational Model For Sustainable And Healthy Online Learning. Sustainability (Switzerland), 13(5), 1-21. https://doi.org/10.3390/su13052546

Bahasoan, A. N., Ayuandiani, W., Mukhram, M., \& Rahmat, A. (2020). Effectiveness of online learning in pandemic COVID-19. International Journal of 
Science, Technology \& Management, 1(2), 100-106. https://doi.org/10.46729/ijstm.v1i2.30

Balram, A (2020, April 18). The Johns Hopkins NewsLetter. How Online Learning Can Affect Student Health.

https://www.jhunewsletter.com/article/2020/04/howonline-learning-can-affect-student-health

Balyer, A., \& Oz, O. (2018). Academicians' Views on Digital Transformation In Education. International Online Journal of Education and Teaching (IOJET), 5(4), 809-830. http://iojet.org/index.php/IOJET/article/view/441/295

Basilaia, G. (2020). Replacing the Classic Learning Form at Universities as an Immediate Response to the COVID19 Virus Infection in Georgia. International Journal for Research in Applied Science and Engineering Technology, 8(3), 101-108. https://doi.org/10.22214/ijraset.2020.3021

Belay, D. G. (2020). COVID-19, Distance Learning and Educational Inequality in Rural Ethiopia. Pedagogical Research,5(4),em0082. https://doi.org/10.29333/pr/9133

Büyükahıska, D., \& Uyar, A. C. (2019). İngilizcenin Yabanc1 Dil Olarak Okutulduğu Sınıflarda Farklı Aksanların Dinleme Becerisine Etkileri. OPUS Uluslararası Toplum Araştırmaları Dergisi, March, 1-1. https://doi.org/10.26466/opus.610859

Chien, C., Huang, Y., \& Huang, P. (2020). YouTube Videos on EFL College Students' Listening Comprehension. English Language Teaching, 13(6), 96. https://doi.org/10.5539/elt.v13n6p96

Chriscaden, K. (2020, 13 October). Impact of Covid-19 On People's Livelihoods, Their Health and Our Food Systems. https://www.who.int/news/item/13-10-2020impact-of-covid-19-on-people's-livelihoods-theirhealth-and-our-food-systems

Churiyah, M., Sholikhan, S., Filianti, F., \& Sakdiyyah, D. A. (2020). Indonesia Education Readiness Conducting Distance Learning in Covid-19 Pandemic Situation. International Journal of Multicultural and Multireligious Understanding, 7(6), 491-507. http://dx.doi.org/10.18415/ijmmu.v7i6.1833

Destianingsih, A., \& Satria, A. (2020). Investigating Students' Needs for Effective English Online Learning During Covid-19 for Polbeng Students. ELT-Lectura, 7(2), 147-153. https://doi.org/10.31849/eltlectura.v7i2.4657
Djabborova, F. O. (2020). Ways of Developing Listening Skills of English. European Journal of Research and Reflection in Educational Sciences, 8(10), 212-216. https://www.idpublications.org/wpcontent/uploads/2020/10/Full-Paper-WAYS-OFDEVELOPING-LISTENING-SKILLS-OFENGLISH-LEARNERS-IN-ESL-AND-EFL.pdf

Efriana, L. (2021). Problems of Online Learning during Covid-19 Pandemic in EFL Classroom and the Solution. Journal of English Language Teaching and Literature, 2(1), 38-47. https://jurnal.stkipmb.ac.id/index.php/jelita/article/vie w/74

Fachriza, A. (2020). The Implementation of Podcast Audio on Teaching Listening comprehension. IJELAL International Journal of English Learning and Applied Linguistics, $\quad 1(1), \quad 12-25$. http://dx.doi.org/10.21111/ijelal.v1i1.5001

Faliyanti, E. (2017). The Influence Of English Song Toward Students'vocabulary Mastery And Students'motivation. Premise: Journal of English Education and Applied Linguistics, 6(1), 77-84. http://dx.doi.org/10.24127/pj.v6i1.785

Fitriani, Y., Bandung, M., \& Kadri, M. K. (2020). Humanitatis Journal of Language and Literature Students' Perspective of Online Learning on Speaking Class During Covid-19 Pandemic. Humanitatis : Journal of Language and Literature, 7(1), 1-12. https://journal.universitasbumigora.ac.id/index.php/h umanitatis/

Gajšt, N. (2014). Business English As A Lingua Franca-A Cross-Cultural Perspective of Teaching English For Business Purposes. ELOPE: English Language Overseas Perspectives and Enquiries, 11(2), 77-87. https://doi.org/10.4312/elope.11.2.77-87

Gu, Y. (2018). Two-way listening. The TESOL Encyclopedia of English Language Teaching, 1-8. https://doi.org/10.1002/9781118784235.eelt0578

Halili, S. H., \& Zainuddin, Z. (2015). Flipping the Classroom: What We Know and What We Don't. The Online Journal of Distance Education and e-Learning ,3(1), $15-22$. https://tojdel.net/journals/tojdel/articles/v03i01/v03i0 1-04.pdf

Hamid, S. M. (2020). Online Digital Platforms During Covid-19 in Efl Classes: Visual Impairment Student' Perception. ETERNAL (English, Teaching, Learning, 
and Research Journal), 6(2), 328. https://doi.org/10.24252/eternal.v62.2020.a10

Hanus, K. (2016). Factors That Influence Learning by English Language Learners (ELLs). BU Journal of Graduate Studies in Education, 8(2), 19-22. https://files.eric.ed.gov/fulltext/EJ1230510.pdf

Hu, J., \& Hu, X. (2020, November). The Effectiveness of Autonomous Listening Study and Pedagogical Implications In the Module of Artificial Intelligence. Journal of Physics: Conference Seriess, 1684(1) 012037). $6596 / 1684 / 1 / 012037$ https://doi.org/:10.1088/1742-

Irawan, A. W., Dwisona, \& Lestari, M. (2020). Psyhological Impacts of Students On Online Learingdurung $\mathrm{He}$ Pandemic COVID-19. Konseli: Jurnal Bimbingan Dan Konseling (E-Journal), 07(1), 53-60. https://doi.org/10.24042/kons.v7i1.6389

Izzah, L., \& Keeya, K. (2019). Common Listening Challenges: Indonesian EFL Learners' Perception. English Language in Focus (ELIF), 1(2), 95. https://doi.org/10.24853/elif.1.2.95-106

Jackson, C., Vynnycky, E., \& Mangtani, P. (2016). The Relationship between School Holidays and Transmission of Influenza in England and Wales. American Journal of Epidemiology, 184(9), 644-651. https://doi.org/10.1093/aje/kww083

Kasap, B. (2016). A case study on the analysis of the worksheets used in a language preparatory school in higher education. International Journal of Languages ' Education, 14), 36-36. https://doi.org/10.18298/ijlet.643

Kholida, E. N. (2016). Enhancing Listening Skill Based on Authentic Materials in Higher Education. DEIKSIS, 8(03), 256-266. http://dx.doi.org/10.30998/deiksis.v8i03.809

Liguori, E., \& Winkler, C. (2020). From Offline to Online: Challenges and Opportunities for Entrepreneurship Education Following the COVID-19 Pandemic. Entrepreneurship Education and Pedagogy, 3(4), 346-351. https://doi.org/10.1177/2515127420916738

Lischer, S., Safi, N., \& Dickson, C. (2021). Remote learning and students' mental health during the Covid-19 pandemic: A mixed-method enquiry. Prospects, 1-11. https://doi.org/10.1007/s11125-020-09530

Male, H., Murniarti, E., Simatupang, M., Siregar, J., Sihotang, H., \& Gunawan, R. (2020). Atittude of
Undergraduate Student'S Towards Online Learning During Covid-19 Pandemic. Palarch's Journal of Archaeology of Egypt / Egyptology, 17(4), 1628-1637. https://archives.palarch.nl/index.php/jae/article/view/ $\underline{1746}$

Murayama, K., FitzGibbon, L., \& Sakaki, M. (2019). Process account of curiosity and interest: A reward-learning perspective. Educational Psychology Review, 31(4), 875-895. https://doi.org/10.1007/s10648-019-09499-9

Nor, H. (2015). the Techniques in Teaching Listening Skill. Journal on English as a Foreign Language, 4(1), 41. https://doi.org/10.23971/jefl.v4i1.74

Nowrouzi, S., Tam, S. S., Zareian, G., \& Nimehchisalem, V. (2015). Iranian EFL Students' Listening Comprehension Problems. Theory and Practice in Language Studies, 5(2), 263. https://doi.org/10.17507/tpls.0502.05

Nushi, M., \& Orouji, F. (2020). Investigating EFL Teachers' Views on Listening Difficulties Among Their Learners: The Case of Iranian Context. SAGE Open, 10(2). https://doi.org/10.1177/2158244020917393

Padmo, D., Sri Ardiasih, L., \& Idrus, O. (2020). Online Learning During the Covid-19 Pandemic and Its Effect on Future Education in Indonesia. In Ljupka Naumovska (Ed.), The Impact of COVID19 On the International Education System (71-86). https://doi.org/10.51432/978-1- 8381524-0-6_5

Perveen, A. (2016). Synchronous and Asynchronous ELanguage Learning: A Case Study of Virtual University of Pakistan. Open Praxis, 8(1), 21-39. https://doi.org/10.5944/openpraxis.8.1.212

Prihandoko, L. A., Tembang, Y., Marpaung, D. N., \& Rahman, F. (2019, October). English language competence for tourism sector in supporting socioeconomic development in Merauke: A Survey Study. In IOP Conference Series: Earth and Environmental Science (Vol. 343, No. 1, p. 012170). IOP Publishing.

Putri, N. S. (2020). The Teaching of Listening in A Pesantren-based University during Covid-19 Pandemic. IJELAL (International Journal of English Learning and Applied Linguistics), 1(1), 56-77. http://dx.doi.org/10.21111/ijelal.v1i1.5014

Putri, S. E., Hamuddin, B., Nursafira, M. S., \& Derin, T. (2020). Discourse Analysis in E-Learning-Based Course Using Moodle Platform: An Experimental Design . REiLA : Journal of Research and Innovation 
in $\quad$ Language, 2(1),

https://doi.org/10.31849/reila.v2i1.3960

Qiong, O. U. (2017). A Brief Introduction to Perception. Studies in Literature and Language, 15 (4), 18-28. http://dx.doi.org/10.3968/10055

Rahim, M. N., \& Chandran, S. S. C. (2021). Investigating EFL Students' Perceptions on E-learning ParadigmShift During Covid-19 Pandemic. Elsya : Journal of English Language Studies, 3(1), 56-66. https://doi.org/10.31849/elsya.v3i1.5949

Rost, M. (2011). Teaching and researching listening (2nd ed.). Harlow, England: Longman https://www.academia.edu/2601642/Teaching_Listen ing_Cambridge_?auto=download

Saintika, Y., Astiti, S., Kusuma, D. J. A., \& Muhammad, A. W. (2021). Analysis of e-learning readiness level of public and private universities in Central Java, Indonesia. Regist. J. Ilm. Teknol. Sist. Inf, 7, 15-30. https://doi.org/10.26594/register.v7i1

Schmidt, A. (2016). Listening Journals for Extensive and Intensive Listening Practice. English Teaching Forum, 2(54)

$2-11$. https://files.eric.ed.gov/fulltext/EJ1104020.pdf

Setyowati, L., Sukmawan, S., \& El-Sulukkiyah, A. A. (2021). Learning from home during pandemic: A blended learning for reading to write activity in EFL setting. JEES (Journal of English Educators Society), 6(1), 9-17. https://doi.org/10.21070/jees.v6i1.662

Singh, C. K. S., \& Jeganmohan, S. (2020). A Review of Studies on action Songs among ESL Learners to Improve English. International Journal of Psychosocial Rehabilitation, 24(05). https://doi.org/ 10.37200/IJPR/V24I5/PR201932

Son, C., Hegde, S., Smith, A., Wang, X., \& Sasangohar, F. (2020). Effects of COVID-19 on college students' mental health in the United States: Interview survey study. Journal of medical internet research, 22(9), e21279. https://doi.org/10.2196/21279

Strielkowski, W. (2020). COVID-19 Pandemic and The Digital Revolution in Academia and Higher Education. Preprints, April 1-6. https://doi.org/10.20944/preprints202004.0290.v1

Sundarasen, S., Chinna, K., Kamaludin, K., Nurunnabi, M., Baloch, G. M., Khoshaim, H. B., Hossain, S. F. A., \& Sukayt, A. (2020). Psychological impact of covid-19 and lockdown among university students in malaysia:
Implications and policy recommendations. International Journal of Environmental Research and Public Health, 17(17), 1-13. https://doi.org/10.3390/ijerph17176206

Sundari, W. (2018). The Difficulties of Learning English for the Basic English Learners. Journal of Cultural, Literary, and Linguistic Studies, 2(1), 34-41. https://ejournal2.undip.ac.id/index.php/culturalistics/a rticle/view/2050/1367

Suprianto, S., Arhas, S. H., \& Mahmuddin, M. (2020). The Effectiveness of Online Learning Amid the COVID19 Pandemic. Jurnal Ad'ministrare, 7(2), 321-330. https://doi.org/10.26858/ja.v7i2.16441

Surayatika, D. (2017). Using website as a tool for practicing English listening skill. Global Expert: Jurnal Bahasa dan Sastra, 6(1). https://core.ac.uk/download/pdf/230621257.pdf

Susilowati, R. (2020). The Challenges of Online Learning in Listening Class During Covid-19 Pandemic. Edukasi Lingua Sastra, 18(2), 56-72. https://doi.org/10.47637/elsa.v18i2.290

Syafiq, A. N., Rahmawati, A., Anwari, A., \& Oktaviana, T. (2021). Increasing Speaking Skill through YouTube Video as English Learning Material during Online Learning in Pandemic Covid-19. Elsya : Journal of English Language Studies, 3(1), 50-55. https://doi.org/10.31849/elsya.v3i1.6206

The United Nations Educational, Scientific and Cultural Organization. (2020). 1.3 Billion Learners Are Still Affected by School or University Closures, As Educational Institutions Start Reopening Around The World, Says UNESCO. https://en.unesco.org/news/13-billion-learners-arestill-affected-school-university-closures-educationalinstitutions

Ulum, O. G. (2015). International Journal of Humanities Social Sciences and Education (IJHSSE) Listening: The Ignored Skill in EFL Context. International Journal of Humanities Social Sciences and Education, 2(5), 72-80. www.arcjournals.org

Utomo, M. N. Y., Sudaryanto, M., \& Saddhono, K. (2020). Tools and Strategy for Distance Learning to Respond COVID-19 Pandemic in Indonesia. Journal homepage: https://doi.org/10.18280/isi.250314

Wulanjani, A. N., \& Indriani, L. (2021). Revealing Higher Education Students' Readiness for Abrupt Online Learning in Indonesia amidst Covid-19. NOBEL: 
Journal of Literature and Language Teaching, 12(1), 43-60.

https://doi.org/10.15642/NOBEL.2021.12.1.43-59

Yang, C., Chen, A., \& Chen, Y. (2021). College Students' Stress and Health In The COVID-19 pandemic: The Role Of Academic Workload, Separation From School, And Fears Of Contagion. PLoS ONE, $16(2$ February), $1-16$. https://doi.org/10.1371/journal.pone.0246676

Yunita, W., \& Jumiyanti, J. (2020). Exploring the Correlation Between Students' Interest in Listening and Listening Comprehension in English Context. Utamax: Journal of Ultimate Research and Trends in Education, 2(3), 133-139. https://doi.org/10.31849/utamax.v2i3.6162

Zahidi, M. A. (2014). Failure Factors of Teaching English as a Second Language Students in teaching Graduate Programme at Institute of Teacher Education. American Journal of Educational Research, 2(10), 850-855. https://doi.org/10.12691/education-2-10-2

Zulfikar, Z., Aulia, C. T., \& Akmal, S. (2020). Exploring Efl Students' Problems in Listening To English News Broadcasts. Language Literacy: Journal of Linguistics, Literature, and Language Teaching, 4(2), 340-352. https://doi.org/10.30743/11.v4i2.2940 